\title{
PROSEDUR DAN SISTEM PENGENDALIAN INTERN DALAM PEMBERIAN KREDIT PADA KOPERASI SIMPAN PINJAM CIPTA MULIA DESA BONDALEM
}

\author{
Uun Ratdyanti Sasmitha \\ Jurusan Akuntansi Program Diploma III, \\ Universitas Pendidikan Ganesha, Singaraja \\ Uunratdyanti@yahoo.com
}

\begin{abstract}
Abstrak
Penelitian ini bertujuan untuk mengetahui, (1) Prosedur Pemberian Kredit pada Koperasi Cipta Mulia Desa Bondalem, (2) Penerapan Sistem Pengendalian Intern dalam Pemberian Kredit pada Koperasi Simpan Pinjam Cipta Mulia Desa Bondalem. Teknik pengumpulan data yang digunakan yakni, metode wawancara, metode dokumentasi dan metode observasi. Subjek penelitian adalah KSP Cipta Mulia Desa Bondalem dan objek penelitian adalah prosedur dan sistem pengendalian intern dalam pemberian kredit. Data yang digunakan adalah data kualitatif.

Hasil penelitian menunjukan bahwa (1) Prosedur Pemberian Kredit KSP Cipta Mulia Desa Bondalem sudah baik dapat dilihat dari prosedur pemberian kredit, bagian yang terkait dalam pemberian kredit, dokumen yang digunakan dalam pemberian kredit, catatan akuntansi yang digunakan dalam pemberian kredit yang dapat di gambarkan bagan aliran prosedur pemberian kredit ( flowchat ), (2) Sistem Pengendalian Intern yang diterapkan pada Koperasi Simpan Pinjam Cipta Mulia Desa Bondalem dalam Pemberian Kredit tersebut sudah berjalan dengan baik, dibuktikan dengan diterapkannya unsur-unsur Sistem Pengendalian Intern.
\end{abstract}

Kata Kunci : Prosedur, Sistem Pengendalian Intern, Kredit dan Koperasi

This study is aimed at investigating (1) the proceduee of credit granting in Koperasi Cipta Mulia Desa Bondalem, (2) the implementation of intern controlling system on credit granting in Koperasi Simpan Pinjam Cipta Mulia Desa Bondalem. The techniques used for data collection are interview method, documentation method, and observation method. The subject of this study is KSP Cipta Mulia Desa Bondalem and the object of this study is the procedure and the intern controlling system in granting credits. The data used are qualitative data. Next, the data are analyzed with qualitative descrptive analysis.

The result of the study shows that (1) the procedure of granting credits KSP Cipta Mulia Desa Bondalem is good and satisfying, it can be seen from the procedure of granting credits, the sections involved in granting credits, the accounting note used in granting credits that is depictedin a flowchat, (2) the intern controlling system implemented in Koperasi Simpan Pinjam Cipta Mulia Desa Bondalem in granting credits has been well conducted, it is proven from the elements of intern controlling system implemented in Koperasi Simpan Pinjam Cipta Mulia.

Keywords: Procedure, Intern Controlling System, Credits, and Cooperation. 


\section{Pendahuluan}

Lembaga keuangan memiliki peranan yang sangat penting dalam menunjang kesejahteraan masyarakat di suatu negara. Di Indonesia mayoritas warga negaranya bergantung pada lembaga keuangan untuk mendapatkan bantuan pendanaan dan tempat untuk menyimpan uang. Saat ini bank masih menjadi primadona masyarakat untuk mendapatkan bantuan keuangan dan menyimpan uangnya. Namun tidak dapat dipungkiri bahwa koperasi juga mendapatkan kepercayaan dari masyarakat, terutama masyarakat menengah ke bawah.

Perekonomian masyarakat Indonesia sedang mengalami pertumbuhan dan perkembangan, salah satunya adalah perekonomian masyarakat pedesaan. Diperlukan peran dari berbagai pihak khususnya lembaga keuangan maupun lembaga non bank untuk mendukung perekonomian masyarakat tersebut, sehingga tumbuh dan berkembang dengan cepat. Peran dari lembaga keuangan maupun lembaga non bank tersebut adalah untuk ikut secara nyata meningkatkan pendapatan dan kesejahteraan anggotanya agar mampu mengatasi ketimpangan ekonomi dan kesenjangan sosial, sehingga lebih mampu berperan sebagai wadah kegiatan ekonomi rakyat. Untuk mewujudkan hal tersebut diperlukan sistem pengendalian intern yang tepat.

Penerapan Sistem Pengendalian Intern yang lakukan oleh lembaga keuangan maupun lembaga non bank selama ini kadang belum berjalan sesuai dengan ketentuan yang berlaku. Hal ini karena masih adanya sistem pengendalian intern dengan prosedur prosedur yang masih kurang tepat saat melakukan kegiatan oprasional perusahaan. Oleh karena itu, perlu mendapat perhatian pada prosedur dan sistem pengendalian intern agar tidak menggagu kelancaran oprasional lembaga keuangan maupun lembaga non bank.

Salah satu lembaga keuangan non bank yang menerapkan prosedur dan Sistem Pengendalian Intern untuk mempercepat tumbuh dan berkembangnya masyarakat desa adalah koperasi. Berdasarkan fenomena tersebut, maka koperasi maupun lembaga keuangan lainnya memerlukan Sistem Pengendalian Intern yang didalamnya terdapat prosedur-prosedur yang harus dipatuhi oleh koperasi.

Koperasi merupakan salah satu bentuk oganisasi ekonomi yang sedang mendapatkan perhatian pemerintah. Koperasi merupakan organisasi yang berbadan hukum. Koperasi harus dibangun untuk menciptakan usaha dan pelayanan dalam menciptakan azas kekeluargaan. Koperasi sebagai badan usaha harus senantiasa diarahkan dan didorong untuk ikut berperan secara nyata meningkatkan pendapatan dan kesejahteraan anggotanya agar mampu mengatasi ketimpangan ekonomi dan kesenjangan sosial, sehingga lebih mampu berperan sebagai wadah kegiatan ekonomi rakyat.

Koperasi dapat dikatakan baik operasionalnya apabila memiliki sistem pengendalian intern yang memadai dan prosedur yang mudah diterima dalam menjalankan kegiatan usahanya. Hal ini dimaksudkan untuk mencegah terjadinya penyimpangan yang mungkin dilakukan baik dari sisi intern, ataupun kelancaran operasional koperasi.

Penerapan Sistem Pengendalian Intern pada koperasi juga dapat mengalami permasalah, salah satunya dalam sistem pengendalian kredit. Kemudian prosedur pemberian kredit juga harus benar-benar memperhitungkan resiko-resiko yang mungkin akan timbul dalam pemberian kredit yang disalurkan, seperti misalnya kredit macet atau penyelewengan terhadap kredit yang akan diberikan kreditur kepada debitur. Oleh karena itu, kredit koperasi tidak begitu saja diperoleh bagi masyarakat yang membutuhkan. Hal tersebut dapat dihindari dengan adanya penerapan Sistem Pengendalian Intern dalam pemberian kredit yang baik yang telah ditetapkan pada koperasi sehingga dapat menunjang efektivitas pemberian kredit oleh koperasi kepada masyarakat.

Kredit merupakan produk koperasi yang memiliki tingkat resiko yang paling tinggi, sehingga koperasi harus berhati-hati dalam memberikan kredit. Masalah keamanan atas kredit yang diberikan merupakan masalah yang harus diperhatikan oleh koperasi, karena adanya resiko yang timbul dalam pemberian kredit. Permasalahan ini bisa dihindari dengan adanya suatu Sistem Pengendalian Intern yang memadai dalam bidang perkreditan. Dengan kata lain diperlukan suatu Sistem Pengendalian Intern yang dapat menunjang 
efektivitas pemberian kredit. Dengan terselenggaranya Sistem Pengendalian Intern yang memadai dalam bidang perkreditan, berarti menunjukkan sikap kehati-hatian dalam tubuh koperasi tersebut.

Untuk mampu berperan sebagai badan usaha yang tangguh dan mandiri, koperasi melalui usaha pemberian kreditnya mampu meningkatkan efektivitas pemberian kredit dan berusaha sebaik mungkin mengurangi resiko kegagalan kredit. Jika diteliti lebih dalam, kegagalan kredit disebabkan oleh lemahnya Sistem Pengendalian Intern.

Menurut Gatot Suparmono, SH ( 1997 : 131) bahwa kredit macet adalah suatu keadaan dimana seorang nasabah tidak mampu membayar lunas kredit bank tepat pada waktunya.

Salah satu koperasi yang menerapkan Prosedur dan Sistem Pengendalin Intern dalam Pemberian Kredit adalah Koperasi Simpan Pinjam Cipta Mulia Desa Bondalem. Dalam penilaian penyaluran kredit pada koperasi Simpan Pinjam Cipta Mulia Desa Bondalem meimplementasikan Prosedur dan Sistem Pengendalian Intern dalam Pemberian Kredit sudah berjalan dengan baik karena kredit macet yang pernah dialami koperasi Simpan Pinjam Cipta Mulia sudah dapat diatasi dengan Sistem Pengendalian Intern.

Berikut adalah data nasabah kredit macet dari tahun 2009 - 2014 tergambar dalam tabel 1 berikut ini :

\begin{tabular}{|c|c|}
\hline Tahun & Jumlah Kredit \\
\hline 2009 & $5.578 .050,-$ \\
\hline 2010 & 5.233.900,- \\
\hline 2011 & 20.015.670,- \\
\hline 2012 & 2.690.500,- \\
\hline 2013 & $22.025 .850,-$ \\
\hline 2014 & 13.965.000,- \\
\hline
\end{tabular}

Data tabel 1 diatas dilihat bahwa terjadi kredit macet dari tahun ke tahun secara fluktuasi. Itu karena kredit macet tersebut sudah diatasi oleh pihak koperasi itu sendiri. Untuk meminimalisasikan kredit macet, diperlukannya Sistem Pengendalian Intern dari pihak koperasi agar lebih meningkatkan control saat koperasi memberikan kredit sehingga koperasi bisa mendapatkan laba yang optimal dan citra koperasi dalam hal ini adalah KSP Cipta Mulia menjadi lebih baik.

\section{Metode Penelitian}

Tujuan yang ingin dicapai dari penelitian ini adalah untuk mengetahui Prosedur Pemberian Kredit Koperasi Simpan Pinjam Cipta Mulia Desa Bondalem dan untuk mengetahui Penerapan Sistem Pengendalian Intern dalam Pemberian Kredit pada Koperasi Simpan Pinjam Cipta Mulia Desa Bondalem. Pada penelitian ini, data yang dipergunakan adalah data kualitatif yang merupakan data yang dari non angka yang bersifat deskriptif, berupa gambaran umum perusahaan, struktur organisasi perusahaan, serta data - data lain yang dibutuhkan oleh penulis dalam penelitian ini. Agar tujuan penelitian dapat tercapai, maka peneliti melakukan pengumpulan data dengan mengunakan metode wawancara, yaitu melakukan wawancara langsung terhadap responden untuk memperoleh informasi yang dibutuhkan. Dokumentasi, yaitu teknik pengumpulan data dengan cara mengumpulkan dokumen-dokumen yang berkaitan dengan pemberian kredit. Observasi, yaitu mengadakan pengamatan langsung pada Koperasi Simpan Pinjam Cipta Mulia Desa Bondalem, dengan tujuan untuk mendapatkan data-data yang diperlukan dalam penelitian ini. Setelah 
pengumpulan data maka data tersebut akan dilakukan pengolahan data. Setelah itu dilakukan analisis data dengan menggunakan metode analisis deskriptif kualitatif. Metode analisis deskriptif kualitatif yaitu menganalisis, menggambarkan, dan meringkas berbagai kondisi, situasi dari berbagai data yang dikumpulkan berupa hasil wawancara atau pengamatan mengenai masalah yang diteliti yang terjadi di lapangan. Metode analisis deskriptif kualitatif tersebut dilakukan dengan menguraikan, menyusun, dan mendeskripsikan tentang prosedur dan sistem pengendalian intern dalam pemberian kredit yang diimplementasikan pada Koperasi Simpan Pinjam Cipta Mulia Desa Bondalem sehinnga diperoleh hasil analisis dan kesimpulan mengenai Prosedur dan Sistem Pengendalian Intern dalam Pemberian Kredit yang diberlakukan pada Koperasi Simpan Pinjam Desa Bondalem. Dari teknik analisis ini akan ditemukan hasil penelitian sehingga nantinya dapat ditarik kesimpulan mengenai Prosedur dan Sistem Pengendalian Intern dalam Pemberian Kredit yang diimplementasikan di Koperasi Simpan Pinjam Cipata Mulia Desa Bondalem.

\section{Hasil dan Pembahasan}

Prosedur pemberian kredit Koperasi Simpan Pinjam Cipta Mulia Desa Bondalem

Prosedur pemberian kredit Koperasi Simpan Pinjam Cipta Mulia Desa Bondalem terdiri dari Prosedur pemberian kredit, bagian yang terkait dalam pemberian kredit, dokumen yang digunakan dalam pemberian kredit, catatan akuntansi yang digunakan dalam pemberian kredit serta yang dapat digambarkan dengan Bagan Aliran Prosedur Pemberian Kredit ( flowchat). Prosedur pemberian kredit Koperasi Simpan Pinjam Cipta Mulia Desa Bondalem terdiri dari dua (2) tahapan yaitu Tahapan Prakarsa dan Analisis Kredit dan Tahapan Pemberian Keputusan Kredit.

\section{a. Tahapan Prakarsa dan Analisis Kredit}

Prosedur ini dimulai dari bagian kredit menerima dokumen persyaratan dari calon nasabah, dokumen persyarat ini berupa KTP, KK, surat keterangan jaminan ( STNK, BPKB asli dan surat sertifikat kepemilikan tanah ) kemudian bagian kredit membuat surat permohonan kredit dan memeriksa kelengkapan surat permohonan kredit yang diajukan oleh calon nasabah. Kemudian akan dilanjutkan dengan melakukan survey guna untuk analisis kredit yang dilakukan oleh bagian kredit meliputi pengecekan fisik terhadap barang jaminan dari calon nasabah. Setelah survey selesai dilakukan bagian kredit memberitahu langsung hasil survey kepada calon nasabah (jumlah kredit yang bisa disetujui), dari pemberitahuan tersebut diperoleh keputusan untuk calon nasabah, yaitu diterima atau ditolak, apabila keputusan ditolak maka bagian kredit memberitahuan hasil keputusannya secara lisan kepada nasabah kemudian mengarsipkan dokumen persyaratan kredit.

\section{b. Tahapan Pemberian Putusan Kredit}

Dalam tahapan pemberian putusan kredit, apabila keputusan diterima maka bagian kredit membuat surat persetujuan kredit. Surat persetujuan kredit, surat permohonan kredit dan dokumen persyaratan kredit oleh bagian kredit diserahkan kepada Manajer dan dimintakan otorisasi. Kemudian Manajer menerima dokumen persyaratan kredit, surat permohonan kredit dan surat persetujuan kredit dari bagian kredit untuk diotorisasi. Setelah dokumen tersebut diotorisasi, kemudian diserahkan kepada bagian administrasi umum.

Setelah itu bagian adminiatrasi umum menerima dokumen tersebut dan membuat surat perjanjian pinjaman/kredit rangkap satu dan surat kuasa yang diperlukan rangkap satu, selanjutnya dokumen tersebut diserahkan kepada manajer untuk diotorisasi, setelah diotorisasi dokumen diambil oleh bagian administrasi umum. Kemudian surat perjanjian pinjaman/kredit, surat persetujuan kredit dan surat kuasa yang diperlukan diserahkan kebagian kasir untuk dilakukan pencairan kredit pada nasabah. Kemudian bagian kasir membuat bukti kas keluar dan bukti kas masuk serta membuat Nota Droping pinjaman dan kartu angsuran kredit masing - masing rangkap satu. Bukti kas keluar dan bukti kas masuk divalidasi selanjutnya mencairkan uang tunai 
yang sudah tertuang di nota droping pinjaman kepada nasabah. Selanjutnya kasir menyerahkan kartu angsuran kredit berserta uang tunai kepada nasabah.

Bagian pembukuan menerima dokumen persyaratan kredit, surat permohonan kredit dari bagian administrasi umum, bukti kas keluar ,bukti kas masuk, surat perjanjian pinjaman/kredit, surat kuasa yang diperlukan dan surat persetujuan kredit dari bagian kasir. Bagian pembukuan membuat catatan pinjaman nasabah didalam buku nasabah berdasarkan surat perjanjian pinjaman/kredit, surat permohonan kredit, dokumen persyaratan kredit dan surat kuasa yang diperlukan, surat persetujuan kredit, bukti kas keluar, dan bukti kas masuk. Bagian pembukuan akan mengarsipkan surat perjanjian pinjaman/kredit, surat permohonan kredit, dokumen persyaratan kredit, surat kuasa yang diperlukan dan surat persetujuan kredit secara permanen, sedangkan bukti kas keluar dan bukti kas masuk dicatat ke dalam jurnal kas keluar dan jurnal kas masuk yang selanjutnya akan diposting kedalam buku besar masing - masing.

\section{c. Bagian Yang Terkait:}

(1) Bagian Kredit; (2) Manajer; (3) Bagian Administrasi Umum; (4) Bagian Kasir dan (5) Bagian pembukuan.

\section{d. Dokumen yang digunakan:}

(1) Formulir Permohonan Kredit; (2) Surat Perjanjian Pinjaman/Kredit; (3) Surat Persetujuan Kredit; (4) Bukti Pengeluaran Kas; (5) Bukti Pemasukan Kas dan (6) Dokumen Persyaratan Kredit.

e. Catatan Akuntansi yang Digunakan:

(1) Jurnal Pengeluaran Kas; (2) Jurnal Pemenerimaan Kas; (3) Buku Besar dan (4) Buku Nasabah.

\section{f. Prosedur Pemberian Kredit}

Pertama kali dimulai dari bagian kredit menerima dokumen persyaratan kredit dari calon nasabah, dokumen persyarat kredit ini berupa salinan KTP, KK, surat keterangan jaminan (STNK, BPKB asli dan sertifikat kepemilikan tanah asli) kemudian bagian kredit membuat surat permohonan kredit.

Setelah itu memeriksa kelengkapan surat permohonan kredit yang akan diisi oleh calon nasabah yang mengajukan permohonan pinjaman. Serta memeriksa keabsahan dan kebenaran surat permohonan kredit yang telah diisi oleh calon nasabah oleh bagian kredit, selanjutnya dilakukan survey untuk analisis kredit, survey yang dilakukan oleh bagian kredit meliputi pengecekan fisik terhadap barang jaminan dari calon nasabah. Setelah survey selesai dilakukan bagian kredit memberitahu langsung hasil survey kepada calon nasabah (jumlah kredit yang bisa disetujui ) dari pemberitahuan tersebut diperoleh keputusan untuk calon nasabah, yaitu diterima atau ditolak, apabila keputusan ditolak maka bagian kredit memberitahu hasil keputusannya secara lisan kepada nasabah, kemudian mengarsipkan dokumen persyaratan kredit. Apabila keputusan diterima maka bagian kredit membuat surat persetujuan kredit. Surat persetujuan kredit, surat permohonan kredit dan dokumen persyarat kredit oleh bagian kredit diserahkan kepada manajer dan dimintakan otorisasi. Manajer menerima surat persetujuan kredit, surat permohonan kredit dan dokumen persyaratan kredit dari bagian kredit untuk diotorisasi.

Kemudian bagian kredit mengambil dokumen surat persetujuan kredit, surat permohonan kredit dan dokumen persyaratan kredit yang sudah diotorisasi oleh manajer untuk diserahkan kebagian administrasi umum. Selanjutkan bagian administrasi umum menerima surat persetujuann kredit, surat permohonan kredit, serta dokumen persyaratan kredit yang telah diotorisasi oleh manajer dari bagian kredit. Bagian Administrasi umum membuat surat perjanjian pinjaman/kredit rangkap satu dan surat kuasa yang diperlukan rangkap satu. Bagian administrasi umum menyerahkan dan memintakan otorisasi surat perjanjian pinjaman/kredit dan surat kuasa yang perlukan kepada manajer. Manajer menerima surat perjanjian pinjaman/kredit dan surat kuasa yang diperlukan dan memeriksa surat perjanjian pinjaman/ kredit dan surat kuasa yang diperlukan untuk diotorisasi. Bagian administrasi umum mengambil dokumen surat perjanjian pinjaman/kredit, surat kuasa yang 
diperlukan yang sudah di otorisasi dari manajer. Bagian administrasi umum menyerahkan surat perjanjian pinjaman/kredit, surat persetujuan kredit dan surat kuasa yang diperlukan kepada bagian kasir untuk dilakukan pencairan kredit kepada nasabah.

Selanjutnya Bagian kasir akan menerima surat perjanjian pinjaman/kredit ,surat persetujuan kredit dan surat kuasa yang diperlukan dari bagian Administrasi umum. Bagian kasir membuat bukti kas keluar, bukti kas masuk masing - masing rangkap satu disamping itu bagian kasir membuat nota droping pinjaman dan kartu angsuran kredit yang nantinya akan diserahkan kepada nasabah masing - masing rangkap satu. Setelah itu di bukti kas keluar dan bukti kas masuk masing - masing divalidasi oleh bagian kasir, selanjutnya merealisasikan atau mencairkan uang tunai yang tertuang dalam nota droping yang diserahkan kepada nasabah. Bagian kasir menyerahkan kartu angsuran kredit beserta uang tunai kepada nasabah. Bukti kas keluar, bukti kas masuk, surat perjanjian pinjaman /kredit, surat persetujuan kredit dan surat kuasa yang diperlukan diserahkan kepada bagian pembukuan.

Bagian pembukuan menerima dokumen persyaratan kredit, Surat permohonan kredit dari bagian administrasi umum, bukti kas keluar, bukti kas masuk, surat perjanjian pinjaman/kredit, surat persetujuan kredit serta surat kuasa yang diperlukan dari bagian kasir. Bagian pembukuan membuat catatan pinjaman nasabah didalam buku nasabah berdasarkan surat perjanjian pinjaman/kredit, surat permohonan kredit, dokumen persyaratan kredit dan surat kuasa yang diperlukan, surat persetujuan kredit, bukti kas keluar dan bukti kas masuk. Bagian pembukuan akan mengarsipkan surat perjanjian pinjaman/kredit, surat permohonan kredit, dokumen persyaratan kredit, surat kuasa yang diperlukan dan surat persetujuan kredit secara permanen, sedangkan bukti kas keluar dan bukti kas masuk dicatat ke dalam jurnal kas keluar dan jurnal kas masuk yang selanjutnya akan diposting kedalam buku besar masing - masing.

\section{Penerapan Sistem Pengendalian Intern dalam Pemberian Kredit pada Koperasi Simpan Pinjam Cipta Mulia Desa Bondalem}

Penerapan Sistem Pengendalian Intern dalam Pemberian Kredit pada Koperasi Simpan Pinjam Cipta Mulia Desa Bondalem meliputi Lingkungan Pengendalian (Control Environment), Penaksiran Risiko (Risk Assessment), Aktivitas Pengendalian (Control Activities), Informasi dan Komunikasi (Information and Communication), Pemantauan (Monitoring).

\section{a. Lingkungan Pengendalian (Control Environment)}

Lingkungan pengendalian menekankan pada semua faktor kunci yang secara bersamaan mempengaruhi kebijakan dan prosedur pengendalian. Lingkungan pengendalian meliputi integritas dan nilai etika, komitmen atas kompetensi, filosofi manajemen dan gaya kepemimpinan, struktur organisasi, serta kebijakan sumber daya manusia. Secara umum, lingkungan pengendalian pada KSP Cipta Mulia Desa Bondalem dalam kaitannya dengan pemberian kredit digambarkan sebagai berikut :

1) Integritas dan Nilai Etika

KSP Cipta Mulia Desa Bondalem sangat menjunjung tinggi integritas. Hal ini dapat dilihat dari adanya peraturan - peraturan yang ditetapkan oleh manajemen berupa tata cara kepegawaian mengenai etika dan prilaku. Aturan aturan tersebut kemudian dikomunikasikan kepada setiap karyawan harus dilaksanakan oleh setiap karyawan. Apabila ada karyawan yang tidak melaksanakan aturan - aturan dan kebijakan - kebijakan yang telah ditetapkan tersebut, maka kepada karyawan tersebut akan dikenakan sanksi. Sanksi yang dikenakan tersebut dapat berupa teguran secara lisan, teguran secara tertulis atau surat peringatan.

Selain aturan - aturan KSP Cipta Mulia juga menetapkan kriteria berpakaian untuk para karyawan, yaitu : (1) Hari senin sampai hari Selasa memakai seragam hitam putih (2) Hari rabu dan hari kamis memakai seragam 
endek (3) Hari Jumat memakai koas seragam dan (4) Hari sabtu memakai seragam batik.

Melalui aturan tersebut, manajemen koperasi telah berusaha untuk mengurangi godaan yang mengakibatkan karyawan bertindak tidak jujur, melanggar hukum dan tidak etis.

KSP Cipta Mulia Desa Bondalem memiliki kebijakan dan prosedur pemberian kredit dan hanya dilaksanakan oleh orang-orang yang kompeten. Selain itu, KSP Cipta Mulia Desa Bondalem juga memilki kode etik lisan yang mengatur tentang perilaku. Kode etik tersebut komprehensif dan mencakup halhal seperti pertentangan kepentingan, hal-hal illegal atau tidak benar. Dengan demikian, pihak manajemen akan melakukan tindakan secara intensif untuk menghindari tindakan pegawai atau karyawan yang berbuat tidak jujur.

\section{b. Komitmen atas Kompetensi}

Kompetensi menjadi pertimbangan manajemen untuk melaksanakan tugas tugas tertentu pada KSP Cipta Mulia Desa Bondalem. Kompetensi merupakan suatu pengetahuan dan keahlian yang dipersyaratkan. Adanya uraian tugas secara lisan yang menggambarkan komitmen manajemen kompetensi para pegawai atau karyawannya, seperti KSP Cipta Mulia Desa Bondalem memiliki flowchart prosedur pemberian kredit yang dipahami oleh setiap karyawan yang berada di sana.

Komitmen atas Kompetensi KSP Cipta Mulia sudah cukup baik, hal ini dapat dilihat dari setiap karyawan yang ditempatkan sesuai dengan pendidikan, pengetahuan, keterampilan dan pengalaman.

KSP Cipta mulia menetapkan spesifikasi yang jelas mengenai uraian tugas dan tanggung jawab dari masing - masing karyawan sesuai dengan posisi jabatanya.

\section{c. Filosofi dan Gaya Manajemen}

Dengan adanya filosofi yang dianut oleh Koperasi Simpan Pinjam Cipta Mulia yaitu aman, terarah dan produktif menunjukkan adanya pengendalian terhadap pelaksanaan pemberian kredit. Bila dilihat dari gaya operasinya, sudah ada pemisahan fungsi yang jelas sehingga setiap bagian bertanggung jawab atas pekerjaannya masing-masing.

Filosofi dan gaya manajemen akan berpengaruh terhadap lingkungan pengendalian terutama bila manajemen didominasi oleh satu atau beberapa orang individu. Pada KSP Cipta Mulia Desa Bondalem, manajemen memiliki filosofi dan gaya operasi tertentu yang cukup menunjukkan tindakan-tindakan kreatif, termasuk dalam pemberian kredit kepada nasabah atau debitur.

\section{d. Stuktur Organisasi}

Struktur organisasi merupakan salah satu bentuk komunikasi formal berkaitan dengan lingkungan pengendalian. KSP Cipta Mulia Desa Bondalem memiliki struktur organisasi yang jelas yang menerangkan pembagian tugas, wewenang dan tanggung jawab bagi semua pengurus, pengawas, rapat anggota, manajer maupun karyawan. Misalnya dalam hal pemberian kredit, hanya pejabat yang berwenang dan berhak untuk memberikan keputusan kredit.

e. Kebijakan Sumber Daya Manusia (SDM)

Dari sekian banyak sumber daya yang dimiliki oleh KSP Cipta Mulia, sumber daya manusia (SDM) merupakan sumber daya yang sangat penting. Memiliki SDM yang berkualitas sangat dibutuhkan oleh Koperasi agar tujuan koperasi dapat tercapai. Olehnya itu, KSP Cipta Mulia Desa Bondalem memiliki kebijakan dan prosedur kepegawaian dalam rangka mendapatkan SDM yang jujur dan kompeten terhadap tugasnya.

Kebijakan dan prosedur kepegawaian ini berkaitan dengan komitmen terhadap kompetensi karyawan. KSP Cipta Mulia mempunyai kebijakan dan prosedur kepegawaian, yang dimulai dari adanya prosedur perekrutan karyawan, pembinaan karyawan, termasuk pemberian penghargaan maupun sanksi. 
KSP Cipta Mulia telah menerapkan kebijakan dan prosedur dalam merekrut karyawan sehingga didapat karyawan yang kompeten dan dapat dipercaya untuk mendukung sistem pengendalian intern yang efektif.

KSP Cipta Mulia menetapkan criteria yang jelas mengenai kenaikan gaji, penilaian karyawan, serta pemilihan karyawan yang berprestasi sehingga sebagai penghargaan karyawan yang berprestasi tersebut akan mendapat kenaikan jabatan. Proses penggajian karyawan diberikan secara bulanan. Selain gaji koperasi juga diberikan :

(1) Upah lembur (2) Tunjangan Hari Raya dan (3) Bonus.

Pengaturan jam kerja pada KSP Cipta Mulia telah ditentukan yaitu dari jam 08.00 pagi sampai dengan 14.00 WITA . Selain itu, adanya penjabaran tugas karyawan dan kebijakan terkait dalam hubungannya dengan pelimpahan wewenang dan tanggung jawab menjadi bukti usaha Koperasi Cipta Mulia Desa Bondalem untuk mencapai tujuannya. Koperasi Simpan Pinjam Cipta Mulia juga menyediakan fasilitas-fasilitas berupa jaminan sosial kepada karyawannya, seperti : (a) Pengobatan, diberikan kepada karyawan berupa obat-obatan yang disediakan di koperasi (b) Cuti, diberikan kepada karyawan yang menikah, hamil atau sakit (c) Fasilitas lain, seperti acara tirta yatra, rekreasi yang biasanya di adakan setiap tahun.

\section{2) Penaksiran Risiko (Risk Assessment)}

Pada Koperasi Simpan Pinjam Cipta Mulia setiap organisasi atau perusahaan tentunya akan menghadapi berbagai risiko yang dapat menghalangi pencapaian tujuannya, baik risiko yang berasal dari ekstern perusahaan maupun risiko yang berasal dari intern perusahaan. Risiko ini terkait dengan penetapan tujuan-tujuan yang ingin dicapai organisasi, yaitu efisiensi dan efektivitas operasi, keandalan laporan keuangan dan kepatuhan. Oleh karenanya, setiap organisasi atau koperasi harus melakukan penafsiran risiko secara memadai.

KSP Cipta Mulia Desa Bondalem telah melakukan penaksiran risiko atas kemungkinan salah saji laporan keuangan yang meliputi kejadian-kejadian intern dan ekstern yang timbul karena : (a) Karyawan Baru dalam Aktivitas Pemberian Kredit (b) Perubahan dalam Sistem Informasi Pemberian Kredit (c) Peningkatan Aktivitas Pemberian Kredit (d) Teknologi Baru Dan (e) Keputusan-Keputusan Akuntansi

\section{3) Aktivitas Pengendalian (Control Activities)}

Pada Koperasi Simpan Pinjam Cipta Mulia aktivitas pengendalian merupakan kebijakan dan prosedur yang dibuat untuk memastikan bahwa arahan pimpinan dilaksanakan dengan baik. Unsur-unsur Sistem pengendalian intern yang menyangkut aktivitas pengendalian pada Koperasi Simpan Pinjam Cipta Mulia adalah : a) Pemisahan Tugas yang Cukup (b) Dokumen dan Catatan yang Memadai (c) Pengendalian Fisik atas Aktiva dan Catatan dan (d) Performance Review Pada KSP Cipta Mulia Desa Bondalem adapun aktivitas pengendalian yang dilakukan dalam kaitannya dengan pemberian kredit adalah : (a) Pemberian kredit hanya diberikan otorisasi oleh pejabat yang berwenang. (b) Setiap bukti pemberian kredit dibuat satu rangkap (c) Saldo kredit yang ada dijamin perlindungannya dari kemungkinan besar adanya penipuan. (d) Pencatatan dalam jurnal pemberian kredit didasarkan pada bukti pemberian kredit yang telah diotorisasi oleh pejabat yang berwenang berdasarkan dengan dokumen pemberian kredit (e) Fungsi pemberian kredit dilengkapi oleh alat-alat yang dapat mencegah tindakan penipuan terhadap aktivitas kredit yang dilaksanakan (f) Fungsi yang tidak terlihat dalam saldo pinjaman yang diberikan, pemberian kredit dan pencatatan kredit menggunakan rekening koran koperasi untuk mengecek ketelitian dan keakuratan catatan pemberian kredit (g) Dokumen pemberian kredit diberikan nomor urut yang tercetak dan (h) Untuk menguji kesesuaian jumlah pemberian kredit dengan data kas yang diterima dilakukan dengan pengecekan independen. 


\section{Informasi dan Komunikasi (Information and Communication)}

Pada KSP Cipta Mulia Informasi dan komunikasi diperlukan pada tiap level di dalam organisasi. Informasi dan komunikasi akan mempengaruhi kemampuan manajemen untuk membuat keputusan yang tepat dalam mengelola dan mengendalikan kegiatan organisasi. Sistem Pengendalian Intern pemberian kredit KSP Cipta Mulia Desa Bondalem dalam hal informasi dan komunikasi meliputi :

(a) Adanya sistem informasi yang mencakup catatan - catatan yang menunjukkan semua transaksi pemberian kredit yang sah. (b) Adanya sistem informasi yang mencakup catatan untuk menggambarkan dengan dasar yang tepat atas transaksi-transaksi yang cukup rinci untuk membenarkan pengklasifikasian dari transaksi dalam laporan keuangan secara wajar. (c) Adanya sistem informasi yang mencakup catatan catatan untuk mengukur nilai transaksi pemberian kredit yang benar dalam mencatat nilai keuangannya di dalam laporan keuangan yang wajar. (d) Adanya sistem informasi yang mencakup catatan catatan untuk transaksi pemberian kredit yang berhubungan dengan laporan keuangan secara wajar dalam koperasi simpan pinjam cipta mulia. (e) Adanya sistem informasi yang mencakup catatan catatan dalam hal posting dan pengikhtisaran yang benar atas transaksi transaksi pemberian kredit dan (f) Adanya sistem informasi yang mencakup catatan catatan dalam pengotorisasian transaksi-transaksi pemberian kredit oleh pejabat yang berwenang.

\section{Pemantauan (Monitoring)}

Pemantauan merupakan proses penilaian struktur pengendalian intern sepanjang waktu. Pemantauan struktur sistem pengendalian intern, khususnya dalam hal pemberian kredit pada KSP Cipta Mulia Desa Bondalem dilaksanakan oleh pihak manajemen yaitu bagian analis kredit. Analis kredit melakukan pemantauan dalam rangka menilai efektivitas rancangan dan operasi pengendalian intern pemberian kredit.Selain itu bertugas untuk : (a) Memutuskan seluruh kebijakan perkreditan yang berlaku di KSP Cipta Mulia Desa, misalnya dalam hal menanganan kredit bermasalah dimana manajer memberikan keringan bunga kepada nasabah. (b) Melakukan kajian berkala atas seluruh kebijakan perkreditan (c) Menetapkan target market kredit berikut sektor-sektor yang harus dihindari.Target market kredit yang dimaksud adalah calon - calon debitur atau nasabah kredit yang sangat perlu disasar misalnya pengusaha kontraktor bangunan, usaha dagang pertokoan, kredit sepeda motor dan pedagang - pedagang dipasar tradisional dan (d) Melakukan pemantauan dan evaluasi atas perkembangan dan kualitas portfolio kredit ( kolitibilitas kredit) secara keseluruhan.

\section{4. simpulan dan Saran}

Berdasarkan penelitian yang penulis lakukan pada Koperasi Simpan Pinjam Cipta Mulia Desa Bondalem, penulis dapat menyimpulkan bahwa :

a. Prosedur pemberian kredit sudah baik dan memadai hal ini dapat dilihat dari Prosedur pemberian kredit, bagian yang terkait dalam pemberian kredit, dokumen yang digunakan dalam pemberian kredit, catatan akauntansi yang digunakan dalam pemberian kredit yang dapat di gambarkan bagan Aliran Prosedur Pemberian Kredit (flowchat ).

b. Pada Sistem Pengendalian Intern yang diterapkan pada Koperasi Simpan Pinjam Cipta Mulia Desa Bondalem dalam pemberian kredit tersebut sudah berjalan dengan baik.

$\mathrm{Hal}$ ini dilihat dan dibuktikan dengan adanya unsur-unsur Sistem Pengendalian Intern yang dilaksanakan pada Koperasi Simpan Pinjam Cipta Mulia sebagai berikut : (1) lingkungan Pengendalian, dalam lingkungan pengendalian adanya integeritas dan nilai etika yang sangat dijunjung tinggi, adanya komitmen atas kompetesi, adanya struktur organisasi yang memadai dan penetapan tanggungjawab dan pelimpahan wewenang yang jelas sehingga setiap karyawan dapat mengetahui tugasnya masing-masing dan adanya 
pemisahan tugas dan tanggungjawab atas pemberian kredit serta adanya kebijakan sumber daya manusia yang memadai ; (2) penaksiran Risiko, dengan adanya Penaksiran risiko sehingga dapat mengikuti setiap perkembangan bila terjadi perubahan; (3) aktivitas Pengendalian, dalam aktivitas pengendalian adanya pemisahan tugas yang cukup dan tanggungjawab atas pemberian kredit, adanya penggunaan dokumen dan catatan yang memadai dan adanya pengendalian fisik atas aktiva dan catatan dan adanya performance review ; (4) informasi dan Komunikasi, adanya pelaksanaan sistem informasi dan komunikasi yang didukung oleh prosedur-prosedur dan dokumen yang memadai; (5) pemantauan, dalam Pemantauan yang dilakukan oleh KSP Cipta Mulia adalah adanya memutuskan seluruh kebijakan perkreditan yang berlaku di KSP Cipta Mulia Desa, melakukan kajian berkala atas seluruh kebijakan perkreditan,menetapkan target market kredit berikut sektor-sektor yang harus dihindari, melakukan pemantauan dan evaluasi atas perkembangan dan kualitas portfolio kredit (kolitibilitas kredit) secara keseluruhan.

Berdasarkan penelitian mengenai Prosedur dan Sistem Pengendalian Intern dalam Pemberian Kredit pada Koperasi Simpan Pinjam Cipta Mulia Desa Bondalem maka penulis mencoba memberikan saran yang diharapkan dapat menjadi masukan bagi pihak KSP Cipta Mulia.
a. Bagi KSP Cipta Mulia Desa Bondalem agar lebih berhati-hati dalam memberikan kredit, hal ini agar resiko yang timbul dalam pemberian kredit dapat di minimalisasi.
b. Bagi KSP Cipta Mulia Desa Bondalem agar lebih meningkatkan kualitas sistem pengendalian intern dalam pemberian kredit agar nantinya apabila terjadi hal - hal terhadap kendala atau hambatan - habatan yang mungkin terjadi dalam proses pemberian kredit, sehingga kemungkinan terjadinya kredit kredit macet dapat di cegah sedini mungkin.

\section{Daftar Pustaka}

Ardika, i komang. 2012. KinerjaKeuangan Koperasi Primkoppol SPN Singaraja dilihat dari Aspek Kredit yang Diberikan http://elib.unikom.ac.id/download.php?id=145069

http://elib.unikom.ac.id/files/disk1/127/ibptunikompp-gdl-s1-2007-rimawidiya-6325-bab-ii.pdf, diakses pada tanggal 19 April 2015

http://eprints.uns.ac.id/3481/1/65521706200902181.pdf , diakses pada tanggal 18 April 2015 http://kafeilmu.com/pengertian-kredit-macet/, diakses pada tanggal 19 April 2015

http://repository.unhas.ac.id/bitstream/handle/123456789/8387/SKRIPSI.pdf?sequence $=1$ diakses pada tanggal 19 April 2015

http://repository.widyatama.ac.id/xmlui/bitstream/handle/123456789/3706/Bab\% 202.pdf? sequence $=7$, diakses pada tanggal 19 Maret 2015

http://wsilfi.staff.gunadarma.ac.id/Downloads/files/1032/bagan+alir.pdf diakses pada tanggal 20 Maret 2015

http://www.google.co.id/search?q=evaluasi+sistem+pengendalian+intern+pemberian+kredit+ pada+kasus+bpr+pasar+kabupaten+bonyowali\&spell=1\&sa=X\&ved=0CAwQvwUoA GoVChMl qWhxYmSxgIVBUu8Ch3M-ACo diakses pada tanggal 19 April 2015

Koperasi Simpan Pinjam Cipta Mulia Desa Bondalem.2009. LAPORAN PERTANGGUNG JAWABAN PENGURUS DAN PENGAWASAN

Koperasi Simpan Pinjam Cipta Mulia Desa Bondalem.2014. LAPORAN HASIL KEPUTUSAN RAT XI 